\title{
Pedagogical monitoring as a tool to reduce dropout in distance learning in family health
}

Deborah de Castro e Lima Baesse ${ }^{1 *}$, Alexandra Monteiro Grisolia ${ }^{2}$ and Ana Emilia Figueiredo de Oliveira ${ }^{1}$

\begin{abstract}
Background: This paper presents the results of a study of the Monsys monitoring system, an educational support tool designed to prevent and control the dropout rate in a distance learning course in family health. Developed by UNA-SUS/UFMA, Monsys was created to enable data mining in the virtual learning environment known as Moodle.

Methods: This is an exploratory study using documentary and bibliographic research and analysis of the Monsys database. Two classes (2010 and 2011) were selected as research subjects, one with Monsys intervention and the other without. The samples were matched (using a ration of 1:1) by gender, age, marital status, graduation year, previous graduation status, location and profession. Statistical analysis was performed using the chi-square test and a multivariate logistic regression model with a $5 \%$ significance level.
\end{abstract}

Results: The findings show that the dropout rate in the class in which Monsys was not employed (2010) was $43.2 \%$. However, the dropout rate in the class of 2011, in which the tool was employed as a pedagogical team aid, was $30.6 \%$. After statistical adjustment, the Monsys monitoring system remained in correlation with the course completion variable (adjusted $\mathrm{OR}=1.74$, IC95\% $=1.17-2.59 ; p=0.005$ ), suggesting that the use of the Monsys tool, isolated to the adjusted variables, can enhance the likelihood that students will complete the course. Using the chisquare test, a profile analysis of students revealed a higher completion rate among women (67.7\%) than men (52.2\%). Analysis of age demonstrated that students between 40 and 49 years dropped out the least (32.1 \%) and, with regard to professional training, nurses have the lowest dropout rates (36.3\%).

Conclusions: The use of Monsys significantly reduced the dropout, with results showing greater association between the variables denoting presence of the monitoring system and female gender.

Keywords: Dropout, Distance learning, Pedagogical support, Specialization

Abbreviations: ABRAEAD, Brazilian Statistical Yearbook of Distance Education; DE, Distance education; FHP, Family Health Program; ICTs, Information and communication technologies; INEP, Brazil's National Institute of Educational Studies and Research; INPI, National Institute of Industrial Property; MEC, Ministry of Education; Moodle, Modular Object-Oriented Dynamic Learning Environment; SGTES, Secretary of Labor Management and Health Education; SUS, National Health System; UFMA, Federal University of Maranhão; UNA-SUS, Open University of Brazilian National Health System; VLE, Virtual learning environment

\footnotetext{
* Correspondence: baesse2008@gmail.com

${ }^{1}$ Universidade Aberta do Sistema Único de Saúde - UNA-SUS / Universidade Federal do Maranhão - UFMA, Rua Viana Vaz, 41, Centro, 65020-660 São Luís, Maranhão, Brasil

Full list of author information is available at the end of the article
} 


\section{Background}

The process of teaching and learning is a complex phenomenon. Educational achievement requires students to access learning opportunities, to persist in their learning activities, and to complete the required stages of a course of study. When one of these links in the educational provision breaks, educational failure occurs [1].

Experts disagree on the primary causes for educational failure. Some experts view failure as an individual process, related only to the student's ability to assimilate content. For others, it is an institutional process that results from the organizational form of the curriculum, methodologies and evaluation. Finally, for still others, it is a socio-political process that stems from context [2].

In the research described herein, educational failure is treated as a complex phenomenon involving numerous factors that contribute to "failure to learn" and for which repetition and dropout are the main manifestations [2].

Ashby [3] defines dropout as a student's withdrawal from a course without having completed it successfully and subdivides dropout as follows: temporary interruption (stopout), exit with acquisition of knowledge (attainer), abandonment without getting started (non-starter) and real dropout (dropout). Dropout has long been an important concern among education professionals. This concern is manifest across national contexts and is present in both classroom teaching and distance learning. In our research, the focus is on the distance education (DE) modality.

As noted by Grau-Valldosera [4], Minguillón [5], Baxter [6], Fiuza [7] and Cheng et al. [8], DE dropout rates are a concern for educational institutions in general. In addition, when students start but do not finish their courses, social, academic and economic waste is generated [9-13].

Mezzari et al. [14] note that Brazil's National Institute of Educational Studies and Research (INEP) has released data to facilitate the study of withdrawal. Based on these data, the Brazilian Statistical Yearbook of Distance Education (ABRAEAD) found that approximately one-half of the students (48 \%) who annually enter the DE system in Brazil do not receive their diplomas on time [15].

$\mathrm{DE}$ is a flexible learning method that is based on individual autonomy and convenience of access. DE courses do not have geographic limitations and have high rates of growth [16]. The expansion of DE is of the utmost importance in the democratization of education, particularly with regard to professional development. In addition, the introduction of new information and communication technologies (ICTs) in the labor market is a factor that cannot be ignored.

Normally, DE is offered in a virtual learning environment (VLE) that is specially designed to provide support to DE students. Moodle, the platform employed by the Open University of Brazilian National Health System
(UNA-SUS), boasts over 69 million users in 226 countries, including academic and business users [17].

Anticipating the numerous possibilities that DE creates for healthcare workers' continuing education, Brazil's federal government created UNA-SUS, a project developed by the Ministry of Health, through the Secretary of Labor Management and Health Education (SGTES) and in partnership with several institutions, including the Federal University of Maranhão (UFMA). The goal of UNA-SUS is to qualify professionals who work in the Primary Care Division of the National Health System (SUS) [18]. To that end, UNA-SUS/UFMA has continuously offered specialization courses in Family Health since 2010.

Seeking to continually improve its educational activities, UNA-SUS/UFMA developed the Monsys monitoring system as a pedagogical support tool to control dropout. The research described herein comparatively analyzes the performance of this tool in two DE classes in Family Health, one in which Monsys was not used and another in which Monsys was used. The tool, which was developed and patented by UNA-SUS/UFMA at the National Institute of Industrial Property (INPI) with registration process number BR 512014001542 4, uses PHP programming technologies with JAVASCRIPT and HTML and enables data mining in Moodle. The five authors of the patent are members of the UNA-SUS/ UFMA team.

Moodle stores large amounts of data that are generated by continuous usage by teachers and students. However, Moodle is not a monitoring system and therefore does not organize data in relevant ways-instead, the data are dispersed among the platform pages. The Monsys tool was developed to facilitate and accelerate the collection of relevant data, information and knowledge. Its use was meant to provide more consistent results for a more successful educational process, which includes identifying unsatisfactory performance among students early enough to prevent withdrawal. Monsys helps research teams detect factors associated with dropout in DE courses, thereby contributing to better training of SUS professionals.

A review of the literature shows a gap regarding the effectiveness of pedagogical monitoring in reducing dropout $[19,20]$. We define pedagogical monitoring as the systematic monitoring of students' access to the module and their participation in the courses, the permanent monitoring of the quantity and quality of interventions made by tutors, the progress of activities, and, in particular, the rapid transformation of this information into actions that prevent dropout.

Seeking to investigate how educational management can contribute to processes that prevent dropout, our research supports the hypothesis that systematic monitoring of the 
teaching-learning process and prior knowledge of students' profiles can support pedagogical actions that reduce rates of dropout in the DE context.

\section{The moodle platform and the monsys system}

Moodle is an acronym for Modular Object-Oriented Dynamic Learning Environment [21]. It consists of open source software-allowing users to further develop and improve it-that is used primarily in virtual learning environments.

Throughout the progress of each module, Moodle produces data on the educational history of students, teachers and tutors during the course of each module. Monsys was developed and implemented to facilitate the collection of this information and to improve the courses offered by UNA-SUS/UFMA. When connected to Moodle, Monsys gathers the data collected by the platform and organizes it into a user-friendly interface that allows the pedagogical teams to monitor the activities of students and tutors in order to identify problems and facilitate progress. The main motivation in creating Monsys was to control and reduce dropout.

The opportunity to track students' access to the platform is fundamental to making decisions about reducing or controlling dropout. To monitor those who access the module infrequently or not at all, the UNA-SUS/ UFMA pedagogical supervision team established a flow of actions, which is shown in Fig. 1.

The results of the Monsys analysis shows that transforming data into actionable information can reduce dropout, which corroborates the findings of our research.

\section{Methods}

The project was approved by the University Hospital Research Ethics Committee of the Federal University of Maranhão on $04 / 25 / 2014$ by technical report number 641.915.

The sample consisted of students enrolled in two postgraduate classes in Family Health offered by UNA-SUS/ UFMA in 2010 and 2011. One of these classes was monitored using Monsys, and the other was not. For the analysis, dropout rates were used as a comparative criterion. None of the students in either class received any type of financial incentive or financial aid. To pair the sample, we used the database from the 2010 class $(n=349)$ and $2011(n=753)$. The pairing was implemented considering the gender, age and profession variables at a 1:1 ratio. After pairing, beginning with the smallest class (2010), the final sample was added that was used in the study of 222 matched students from each class. The chisquare test was employed to assess the pairing.

We collected personal identification data (age, gender, marital status), professional data (occupation and place of work), course enrollment at UNA-SUS, the status of each course (graduated, failed, evaded/quit) and student participation in the course from a secondary database in the registration system of UNA-SUS/UFMA.

SPSS was used to run the statistical analysis. Descriptive statistics of the data were generated through the summary measures: absolute and relative frequencies, measures of central tendency (mean or median), dispersion measures (standard deviation or interquartile range) and inter-values estimates (confidence interval at $95 \%$ ). The results are presented in Tables 1, 2, 3, and 4 .

The dependent variable or predictor in this study is the variable related to the existence of dropout (dichotomous), and the main independent variable or predictor is the presence of Monsys (dichotomous). The other independent variables are related to the student's profile and to their performance during the activities developed in the course modules.

To test the hypothesis with the use of categorical variables, we used a chi-square test. The odds ratio (OR) measure and its confidence interval at $95 \%$ were used to measure the association between variables. The significance level is $5 \%$. Multivariate logistic regression analyses were also performed considering the variables with a $p$-value less than 0.20 in the bivariate analysis. In the final model, the adjustment was carried out for the monitoring system, gender, age and profession variables.

The data collected were used for scientific purposes only, and the privacy and confidentiality of the participants involved were protected.

\section{Results}

Table 1 describes the profile of the students in the classes that did not use Monsys as a monitoring tool (Class of 2010) and the classes that did use Monsys (Class of 2011) for the matched variables (gender, age and profession, and marital status). Females accounted for the largest percentage of the sample (69.8\%). In addition, we noted that $50.9 \%$ of the students were between the ages of 22 and 29 and that nursing professionals comprised the largest share of analyzed students (55.9\%).

The association between the use of Monsys and completion of the course is described in Table 2. Notably, in the matched sample of the 2010 class (which had no monitoring system), $56.8 \%$ of students completed the course, whereas the matched class of 2011 presented a completion rate of $69.4 \%$.

Table 3 describes the bivariate association between the covariates and course completion. We observed a higher completion percentage among women $(67.7 \%)$ than men $(52.2 \%)$. Females had a $92 \%$ increase in chance of completion $(\mathrm{OR}=1.92$; CI $95 \%=1.26-2.90 ; p=0.001)$. An age analysis showed that students aged 30 to 39 have a $40 \%$ lower chance of completing the course than 


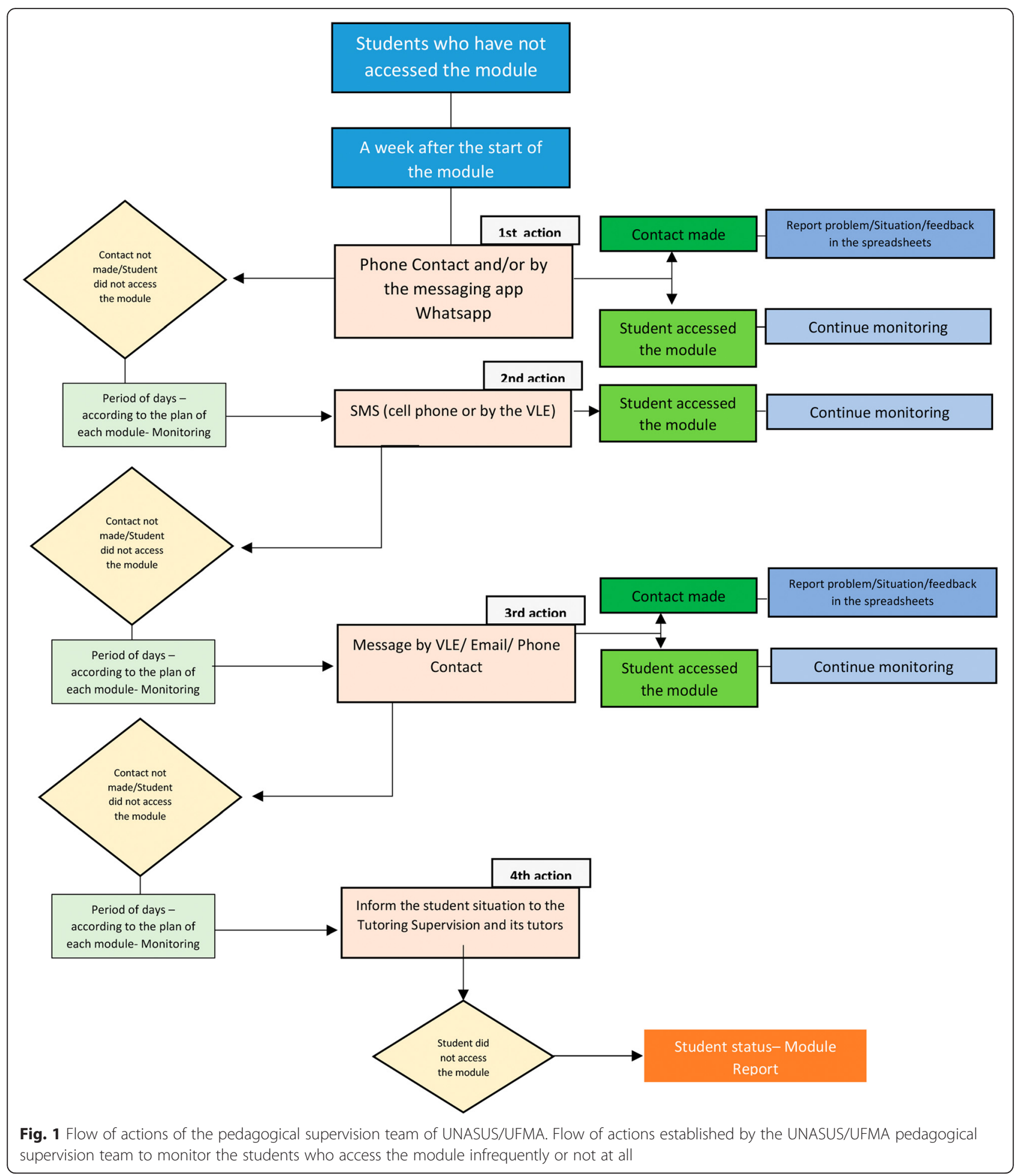

students between 22 and 29 years of age (OR $=0.60$, CI $95 \%=0.38-0.94 ; p=0.025)$. With respect to professional training, the chance that a doctor would complete the course was $57 \%$ lower than the chance that a nurse would $(\mathrm{OR}=0.43$; CI $95 \%=0.23-0.82$; $p=0.011)$.
Table 4 presents the analysis of the multivariate logistic regression model to obtain the adjusted odds ratio. After statistical adjustment, the variable presence of the monitoring system remained in step with course completion (adjusted $\mathrm{OR}=1.74$; CI $95 \%=1.17-2.59 ; p=0.005$ ). 
Table 1 Distribution of profile variables between the analyzed classes and pairing analysis

\begin{tabular}{|c|c|c|c|c|c|}
\hline \multirow[t]{3}{*}{ Variables } & \multicolumn{4}{|c|}{ Monitoring system } & \multirow[t]{3}{*}{$p^{a}$ value } \\
\hline & \multicolumn{2}{|c|}{$\begin{array}{l}\text { Absent } \\
\text { Class 2010 } \\
(N=222)\end{array}$} & \multicolumn{2}{|c|}{$\begin{array}{l}\text { Present } \\
\text { Class 2011 } \\
(N=222)\end{array}$} & \\
\hline & $F$ & $(\%)$ & $f$ & $(\%)$ & \\
\hline Gender & & & & & 1.000 \\
\hline Female & 155 & $(69.8)$ & 155 & $(69.8)$ & \\
\hline Male & 67 & $(30.2)$ & 67 & $(30.2)$ & \\
\hline Age & & & & & 1.000 \\
\hline $22-29$ & 113 & $(50.9)$ & 113 & $(50.9)$ & \\
\hline $30-39$ & 63 & $(28.4)$ & 63 & $(28.4)$ & \\
\hline $40-49$ & 28 & (12.6) & 28 & $(12.6)$ & \\
\hline 50 and up & 18 & (8.1) & 18 & (8.1) & \\
\hline Professional training & & & & & 1.000 \\
\hline Nursing & 124 & $(55.9)$ & 124 & $(55.9)$ & \\
\hline Odontology & 75 & (33.8) & 75 & $(33.8)$ & \\
\hline Medicine & 23 & $(10.4)$ & 23 & $(10.4)$ & \\
\hline Marital status & & & & & 0.763 \\
\hline With partner & 73 & (32.9) & 76 & $(34.2)$ & \\
\hline Without a partner & 149 & $(67.1)$ & 146 & $(65.8)$ & \\
\hline
\end{tabular}

${ }^{a}$ Chi-square test

\section{Discussion}

The purpose of our research was to demonstrate the effectiveness of a monitoring system in the DE modality. As shown in Table 2, the research shows that Monsys contributed to a statistically significant reduction in the dropout rate of approximately $12.6 \%$. The gender, age and students' professional training variables also emerged as factors affecting course completion. By contrast, year of graduation completion, whether there is previous postgraduate education, marital status and the student's professional place of work (in the capital or in the country) did not correlate with the rate of course completion.

We also observed that the highest percentage of matched samples consisted of females (69.8\%). This finding corroborates the findings of Morais et al. [22],

Table 2 Association between use of the monitoring system and the course completion rate

\begin{tabular}{|c|c|c|c|c|c|c|c|}
\hline \multirow{3}{*}{$\begin{array}{l}\text { Monitoring } \\
\text { system }\end{array}$} & \multicolumn{4}{|c|}{ Course completion } & \multirow{3}{*}{$\begin{array}{l}\text { OR } \\
\text { (IC95\%) }\end{array}$} & \multirow{3}{*}{$\begin{array}{l}\text { DR } \\
\text { (IC95\%) }\end{array}$} & \multirow[t]{3}{*}{$p^{\mathrm{a}}$ value } \\
\hline & \multicolumn{2}{|l|}{ Yes } & \multicolumn{2}{|l|}{ No } & & & \\
\hline & $f$ & (\%) & $f$ & (\%) & & & \\
\hline Present & 154 & (69.4) & 68 & (30.6) & $\begin{array}{l}1.72 \\
(1.16-2.54)\end{array}$ & $\begin{array}{l}12.61 \\
(3.71-21.5)\end{array}$ & $0.005^{*}$ \\
\hline Absent & 126 & (56.8) & 96 & $(43.2)$ & Ref. & Ref. & \\
\hline
\end{tabular}

$O R$ odds ratio, $R D$ risk difference, $C l 95 \%$ confidence interval at $95 \%$

*Statistically significant difference

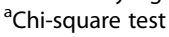

Table 3 Measures of association between covariates and failure to complete the course

\begin{tabular}{|c|c|c|c|c|c|c|}
\hline \multirow[t]{3}{*}{ Variables } & \multicolumn{4}{|c|}{ Course completion } & \multirow[t]{3}{*}{ OR $(95 \% \mathrm{Cl})$} & \multirow[t]{3}{*}{$p^{\text {a value }}$} \\
\hline & \multicolumn{2}{|l|}{ Yes } & \multicolumn{2}{|l|}{ No } & & \\
\hline & $\mathrm{F}$ & (\%) & $f$ & (\%) & & \\
\hline \multicolumn{7}{|l|}{ Gender } \\
\hline Female & 210 & $(67.7)$ & 100 & (32.3) & $1.92(1.26-2.90)$ & $0.001^{*}$ \\
\hline Male & 70 & $(52.2)$ & 64 & $(47.8)$ & Ref. & \\
\hline \multicolumn{7}{|l|}{ Age } \\
\hline $22-29$ & 151 & $(66.8)$ & 75 & $(33.2)$ & Ref. & \\
\hline $30-39$ & 69 & $(54.8)$ & 57 & $(45.2)$ & $0.60(0.38-0.94)$ & $0.025^{*}$ \\
\hline $40-49$ & 38 & $(67.9)$ & 18 & $(32.1)$ & $1.04(0.56-1.95)$ & 0.881 \\
\hline 50 and up & 22 & $(61.1)$ & 14 & (38.9) & $0.78(0.37-1.61)$ & 0.502 \\
\hline \multicolumn{7}{|l|}{ Professional training } \\
\hline Nursing & 158 & $(63.7)$ & 90 & $(36.3)$ & Ref. & \\
\hline Odontology & 102 & $(68.0)$ & 48 & (32.0) & $1.21(0.78-1.86)$ & 0.383 \\
\hline Medicine & 20 & $(43.5)$ & 26 & $(56.5)$ & $0.43(0.23-0.82)$ & $0.011^{*}$ \\
\hline \multicolumn{7}{|l|}{ Marital status } \\
\hline With a partner & 90 & $(60.4)$ & 59 & (39.6) & $0.84(0.56-1.26)$ & 0.409 \\
\hline Without a partner & 190 & $(64.4)$ & 105 & (35.6) & Ref. & \\
\hline \multicolumn{7}{|c|}{ Years since graduation completion } \\
\hline Less than 2 years & 55 & $(68.7)$ & 25 & $(31.3)$ & $1.29(0.69-2.43)$ & 0.414 \\
\hline 2 to 5 years & 111 & $(60.3)$ & 73 & $(39.7)$ & $0.89(0.54-1.48)$ & 0.675 \\
\hline 6 to 10 years & 53 & (63.9) & 30 & $(36.1)$ & $1.04(0.56-1.91)$ & 0.893 \\
\hline $\begin{array}{l}\text { More than } \\
10 \text { years }\end{array}$ & 61 & $(62.9)$ & 36 & $(37.1)$ & Ref. & \\
\hline
\end{tabular}

Previous post graduate
Yes
$\begin{array}{lllllll}50 & (64.1) \quad 28 & (35.9) & 1.05 & (0.63-1.75) & 0.834\end{array}$
No
230 (62.8) $136 \quad$ (37.2) Ref.

Professional place of work

\begin{tabular}{|c|c|c|c|}
\hline In the country & 167 (65.0) & $90 \quad(35.0)$ & $1.21(0.82-179)$ \\
\hline São Luís (Capital) & 113 (60.4) & 74 (39.6) & Ref. \\
\hline
\end{tabular}

OR odds ratio, Cl $95 \%$ confidence interval at $95 \%$ *Statistically significant difference ${ }^{\text {a }}$ Chi-square test

Table 4 Multivariate logistic regression analysis of variables associated with completion rate

\begin{tabular}{lcll}
\hline Variables & Adjusted $\mathrm{OR}^{\mathrm{a}}$ & $(\mathrm{Cl} 95 \%)$ & $p$ value \\
\hline Monitoring System & 1.74 & $(1.17-2.59)$ & $0.005^{*}$ \\
Female & 1.86 & $(1.20-2.86)$ & $0.004^{*}$ \\
Age 30 to 39 years & 0.65 & $(0.41-1.03)$ & 0.072 \\
Doctors & 0.59 & $(0.28-1.24)$ & 0.169 \\
\hline
\end{tabular}

OR odds ratio

*Statistically significant difference

${ }^{a}$ Adjusted regression model for the variables: age group, monitoring system, profession and gender 
Silva et al. [23], Coutinho et al. [24] and Nicholas [25], showing that women make up the majority of students in DE courses.

By contrast, a higher dropout rate among adult female students is described by McGiveny [26]. For this author, the phenomenon results from a combination of family commitments and lack of spousal and/or family support, which creates a conflict between the roles of student, housewife and professional. The results presented in this paper do not support McGivney's vision but instead corroborate the larger body of literature, showing that in addition to comprising more than two-thirds of the students, women had a $92 \%$ greater chance of completing the course than men $(67.7 \%$ versus $52.5 \%)$. This result suggests that when there is an effective and systematic pedagogical supervision of students, such as with Monsys, female students tend to remain more participatory and successfully complete their studies.

Pallof and Pratt [27] argue that the best pedagogical practice in online education is student-centered, which can lead to a reduced dropout rate. Those responsible for organizing DE must be sensitive to students who have learning problems or difficulties with technological instruments and must seek to promote greater interaction such that these students feel recognized as people and not just as virtual students [28].

With respect to age, Mezzari et al. [14] state that the typical DE student is at a more advanced age, which can contribute to problems with the use of technology as a resource and with support. They also emphasize that younger students tend to be more facile at using technology and therefore can more naturally perform VLE tasks. In the present study, however, a correlation was found between the use of Monsys and a lower dropout rate in the 30-39 year age group.

Maciel et al. [29] argue against the claim that older students prefer DE, reporting a trend of younger groups of post-graduate students in DE courses. Yukselturk and Top [30] and Dillie [31] also state that the dominant profile of students in DE no longer consists of individuals over 30 years old and post-graduate students and is becoming a more heterogeneous population with differences in gender and age. This divergence in the predominant age of the typical DE student echoes what Ferreira et al. [32] observed before concluding that there is no defined age group for students attending DE courses and that age is therefore not a fixed variable. The results of our research confirm the trend of younger students in the DE modality, with a predominance of students in the 22-29 year age group.

With regard to professional profiles, nurses comprise the largest share of the students (55.9\%) in the matched samples. These data confirm a trend found in UNASUS/UFMA, in which most students are nurses. Since its foundation in 2010, UNA-SUS/UFMA has enrolled a total of 5883 students [33]. Of these, only 2572 students provided information regarding their academic backgrounds, and 1225 enrollees indicated nursing training on their enrollment form [34].

To better understand this trend, we reviewed the research on higher education courses registered with the Ministry of Education (MEC). In Brazil, there are 784 nursing graduation courses, compared with 223 medicine courses and 219 odontology [35] courses. This discrepancy points to a higher number of nurses in the labor market, which would also explain the fact that these students are in the majority at UNA-SUS. Another factor is that a smaller number of residency options in the nursing field leads to the demand for specialized courses.

The high demand among nurses for specialization in Family Health in the DE Modality may also be attributable to the number of job offers by the Family Health Program (FHP) throughout Brazil. According to Ministry of Health data, the positions offered by the program in 2011 accounted for $11.8 \%$ of the formal job offers for graduates in nursing.

Finally, analysis of the impact of the usage of Monsys in each of the categories studied revealed that its best performance was associated with the following variables: presence of the monitoring system and female gender, both of which remained correlated with course completion.

The positive results obtained in this study can be augmented by other studies that address issues such as the influence of the use of Monsys and the participation and implementation of didactic sequences by tutors, thereby allowing for new qualitative projects.

\section{Conclusion}

This study contributes to the reduction of dropout in $\mathrm{DE}$, a problem that affects people and organizations, bringing personal, social and economic waste. The matched sample of 2011, displaying the same conditions as the matched sample of 2010, maintained a conclusion rate of nearly $70 \%$. This result suggests that efficient pedagogical monitoring is a determining factor in reducing the dropout rate, independent of external factors affecting the process of teaching and learning, including age, gender and profession of the students.

This finding suggests the importance of the pedagogical monitoring made possible with data collected through the use of the Monsys monitoring system, which enabled the pedagogical teams to track the performance of students and tutors in the VLE, accompanying them in their construction of knowledge processes.

It is worth mentioning that, because this is a retrospective study, it was not possible to achieve a more 
qualitative approach, considering the point of view of students and tutors of the sample groups. In addition, the results can not be automatically extrapolated to other institutional realities, since this would require more tests and applications of Monsys in new and varied contexts, something we intend to do within the continuity of this study.

Finally, the pedagogical monitoring made possible with Monsys subverts the logic that it is the student who must fit the institution, adopting strategies to be successful and adapting to the institutional culture. Instead, this study supports the notion that educational institutions also have the responsibility to adjust to different types of students, promoting quality education for all.

\section{Acknowledgements}

None.

\section{Funding}

None.

\section{Availability of data and materials}

The data contained in this study were collected from files used for the internal monitoring of the educational activities of UNA-SUS/UFMA. Therefore, for ethical reasons, the students' identification data was omitted, in order to preserve the confidentiality of the students enrolled in UNA-SUS/ UFMA. More information on the data used in this study may be available upon request. Please contact Deborah Baesse (baesse2008@gmail.com).

\section{Authors' contributions}

DCLB made substantial contributions to conception and design, acquisition of data, analysis and interpretation of data; been involved in drafting the manuscript and in revising it critically for important intellectual content; given final approval of the version to be published. She participated sufficiently in the work to take public responsibility for appropriate portions of the content; and agreed to be accountable for all aspects of the work in ensuring that questions related to the accuracy or integrity of any part of the work are appropriately investigated and resolved. AMG made substantial contributions to conception and design, acquisition of data, analysis and interpretation of data; been involved in drafting the manuscript and in revising it critically for important intellectual content; given final approval of the version to be published. She participated sufficiently in the work to take public responsibility for appropriate portions of the content; and agreed to be accountable for all aspects of the work in ensuring that questions related to the accuracy or integrity of any part of the work are appropriately investigated and resolved. AEFO made substantial contributions to conception and design, acquisition of data, analysis and interpretation of data; been involved in drafting the manuscript and in revising it critically for important intellectual content; given final approval of the version to be published. She participated sufficiently in the work to take public responsibility for appropriate portions of the content; and agreed to be accountable for all aspects of the work in ensuring that questions related to the accuracy or integrity of any part of the work are appropriately investigated and resolved.

\section{Authors' information}

1. Baesse, DCL, EdM, is a professor at the Federal University of Maranhão, with a Master's Degree in Education. She works in the department of Education. She is also a member of the Open University of Brazilian National Health System (UNA-SUS) and of a research group about Technology and Innovation in Health Education.

2. Grisolia, AM, MD, is a professor of Radiology, Coordinator of the discipline of Radiology and a Professor at the Postgraduate Program in Medical Sciences at the Faculty of Medical Sciences in the Rio de Janeiro State University. 3. Oliveira, AEF, DMD, is a professor at the Department of Dentistry at Federal University of Maranhão and at the postgraduate programmes in Dentistry and Adult and Child Health. She is also a coordinator at the Open University of Brazilian National Health System and the President of the Brazilian Council of Telemedicine.

\section{Competing interests}

The authors declare that they have no competing interests.

\section{Consent for publication}

Not applicable.

\section{Ethics approval and consent to participate}

This research was approved by the University Hospital Research Ethics Committee of the Federal University of Maranhão on 04/25/2014 by technical report number 641.915 . This is a retrospective study, in which the data analyzed were collected from concluded courses of UNA-SUS/UFMA using the Monsys monitoring system. The UNA-SUS/ UFMA granted, with a Consent Form of Database Usage signed by its Administrative Manager, the use of the students' data taking into account the principles of research ethics.

\section{Author details}

${ }^{1}$ Universidade Aberta do Sistema Único de Saúde - UNA-SUS / Universidade Federal do Maranhão - UFMA, Rua Viana Vaz, 41, Centro, 65020-660 São Luís, Maranhão, Brasil. ${ }^{2}$ Centro Biomédico, Faculdade de Ciências Médicas, Universidade do Estado do Rio de Janeiro, Av.Vinte e Oito de Setembro, 77, Sala 126, Térreo, Vila Isabel, Rio de Janeiro 20561-030, Rio de Janeiro, Brazil.

Received: 27 May 2016 Accepted: 10 August 2016

Published online: 22 August 2016

References

1. Patto MHSO. Mundo coberto de penas família e Utopia em vidas secas. Estudos Avançados. 2012;76:225-36.

2. Souza RMQ. Regime de Ciclos Com Progressão Continuada nas escolas públicas paulistas: um cenário para o estudo dos impactos das mudanças educacionais no capital cultural e habitus dos professors. In: TEDE - Sistema de Publicação Eletrônica de Teses e Dissertações. Pontifícia Universidade Católica de São Paulo. 2005. https://sapientia.pucsp.br/handle/handle/10397. Accessed 20 May 2014.

3. Ashby A. Monitoring student retention in the Open University: definition, measurement, interpretation and action. Open Learn. 2004;19:65-77.

4. Grau-Valldosera J, Minguillón J. Redefinindo abandono na educação on-line superior: um estudo de caso. In: Proceedings of the 1st International Conference on Learning Analytics and Knowledge: Banff: ACM DL Digital Library; 2011. pp. 290-308.

5. Grau-Valldosera J, Minguillón J. Redefinindo abandono na educação on-line superior: um estudo de caso. In: Proceedings of the 1st International Conference on Learning Analytics and Knowledge: Banff: ACM DL Digital Library; 2011. pp. 290-308.

6. Baxter J. Who am in and what keeps me going? Profiling the distance learning student in higher education. Int Rev Res Open Distance Learn. 2012:13:107-29.

7. Fiuza PJ. Adesão e permanência discente na educação a distância: investigação de motivos e análise de preditores sociodemográficos, motivacionais e de personalidade para o desempenho na modalidade. In: Lume - Repositório Digital. Universidade Federal do Rio Grande do Sul. 2012. http://www.lume.ufrgs.br/bitstream/handle/10183/55089/000855707. pdf? sequence=1. Accessed 20 May 2014.

8. Cheng J, Kulkarni C, Klemmer S. Tools for predicting drop-off in large online classes. In: Conference on Computer Supported Cooperative Work. Stanford: ACM DL Digital Library; 2013. pp. 121-124.

9. Tinto V. Dropout from higher education: a theoretical synthesis of recent research. Rev Educat Res. 1975:45:89-125.

10. Silva Filho RLL, Motejunas PR, Hipólito O, Lobo MBCM. A evasão no ensino superior brasileiro. Cad Pesqui. 2007;37:641-59. http://www.scielo.br/pdf/cp/ v37n132/a0737132.pdf. Accessed 22 May 2014.

11. Park JH, Choi HJ. Factors influencing adult learners' decision to drop out or persist in online learning. The Journal of Educational Technology \& Society. 2009;12:207-17.

12. Nistor N, Neubauer K. From participation to dropout: quantitative participation patterns in on line university courses. Comput Educat. 2012;55:663-72.

13. Leeds $E_{1}$ Campbell S, Baker H, Ali R, Brawley D, Crisp J. The impact of student retention strategies: an empirical study. Int J Manag Educat. 2013;7:22-43.

14. Mezzari A, Tarouco LMR, Avila BG, Machado GR, Favero RVM, Bulegon AM. Estratégias para detecção precoce de propensão à evasão. RIED. 2013;16: 
147-75. http://ried.utpl.edu.ec/sites/default/files/pdf/ried\%2016_2articulos/ art7 estrategias.pdf. Accessed 22 May 2014.

15. Anuário Brasileiro Estatístico de Educação Aberta e a Distância (ABRAEAD): Annual Report (2008). http://www.abraead.com.br/anuario/anuario2007.pdf. Accessed 24 May 2014.

16. Garcia CV. A Importância do Software Livre na Educação a Distância. In: Congresso Nacional Universidade: 6-8 june 2011. Belo Horizonte: Universidade, EaD e Software Livre; 2011. pp. 1-4.

17. Moodle.net: Courses \& Content. Moodle Statistics. https://moodle.net/stats/. Accessed 1 Sep 2015.

18. Universidade Aberta Do Sistema Único De Saúde - Universidade Federal do Maranhão: Curso Saúde da Família. http://www.unasus.ufma.br/site/cursos/ 2014-03-19-19-24-13/2014-03-19-19-28-47/saude-da-familia. Accessed 22 May 2014.

19. Abbad GS, Zerbini T, Souza DBL. Panorama das pesquisas em educação a distância no Brasil. Estud Psicol. 2010;15:291-8.

20. Behar PA. Organizer. Competências em educação a distância. Porto Alegre: Penso; 2013

21. Moodle Docs: About Moodle. https://docs.moodle.org/22/en/About_ Moodle. Accessed 22 May 2014

22. de Morais RS, Viana MDLF, de Camargo RAA. Caracterização dos (as) estudantes de cursos de pós-graduação (Lato sensu) na modalidade de educação a distância. In: Simpósio Internacional De Educação A Distância. Encontro De Pesquisadores De Educação A Distância. 2012. http://sistemas3. sead.ufscar.br/ojs/Trabalhos/164-930-2-ED.pdf. Accessed 22 May 2014.

23. da Silva TAM, Fracolli LA, Chiesa AM. Trajetória profissional na estratégia saúde da família: em foco a contribuição dos cursos de especialização. Revista Latino-Americana de Enfermagem. 2011;19:1.

24. Coutinho CVS, Pistore A, da Cruz MR, Camargo ME. Perfil socioeconômico do aluno de graduação em licenciatura e tecnologia no ensino a distância: estudo de caso em um polo de apoio presencial da Serra Gaúcha. Revista Scientia Plena. 2013;9:2.

25. Nicolau, LS. A estratégia Saúde da Família no município de São Luís: avanços e desafios. Tempus - Acta de Saúde Coletiva. 2009; http://dx.doi. org/10.18569/tempus.v3i2.737.

26. McGiveny RJ. Adult student persistence in online education: developing a model to understand the factors that affect adult student persistence in a course. http://scholarworks.umass.edu/cgi/viewcontent.cgi?article=10178 context=open_access_dissertations(2009). Accessed 21 Nov 2013.

27. Pallof RM, PRATT K. O aluno virtual: um guia para trabalhar com alunos online. Porto Alegre: Artemed; 2004.

28. Sung E, Mayer RE. Five facets of social presence in online distance education. Comput Hum Behav. 2012;28:1738-47.

29. Maciel ELN, et al. Avaliação dos egressos do curso de especialização em saúde da família no espírito santo. Revista Ciência \& Saúde Coletiva. 2010;15:2021-8.

30. Yukselturk E, Top E. Exploring the link among entry characteristics, participation behaviors and course outcomes of online learners: an examination of learner profiles using cluster analysis. BJET. 2012; doi:10.1111/j.1467-8535.2012.01339.x

31. Dillie BK. Identification of high risk telecourse students utilizing locus of control and learning style. https://ttu-ir.tdl.org/ttu-ir/handle/2346/ 10405(1991). Accessed 21 Nov 2013

32. Ferreira, ZN et al. O perfil do aluno de educação a distância no ambiente Teleduc. In: ABED - Associação Brasileira de Educação a Distância. 2007. http://www.abed.org.br/congresso2007/tc/417200794130AM.pdf. Accessed 24 Nov 2013.

33. Plataforma Arouca:Portal do Profissional de Saúde - Versão Beta: O que é a Plataforma Arouca? https://arouca.unasus.gov.br/plataformaarouca/Home. app. Accessed 24 Nov 2013.

34. UNA-SUS - Universidade Aberta do SUS: Bem vindo ao administrador do site v2.5. http://sistemas.unasus.ufma.br/admin/. Accessed 1 Sep 2015.

35. Instituições de Educação Superior e Cursos Cadastrados: e-MEC http://emec.mec.gov.br/. Accessed 1 Sep 2015.

\section{Submit your next manuscript to BioMed Central and we will help you at every step:}

- We accept pre-submission inquiries

- Our selector tool helps you to find the most relevant journal

- We provide round the clock customer support

- Convenient online submission

- Thorough peer review

- Inclusion in PubMed and all major indexing services

- Maximum visibility for your research

Submit your manuscript at www.biomedcentral.com/submit
Biomed Central 